\title{
Statyba
}

\section{TOWARDS THE INTEGRATION OF PROBABILISTIC RISK ANALYSIS WITH STRUCTURAL ANALYSIS}

\section{E. R. Vaidogas}

To cite this article: E. R. Vaidogas (1999) TOWARDS THE INTEGRATION OF

PROBABILISTIC RISK ANALYSIS WITH STRUCTURAL ANALYSIS, Statyba, 5:3, 183-192, DOI:

10.1080/13921525.1999.10531460

To link to this article: https://doi.org/10.1080/13921525.1999.10531460

曲 Published online: 26 Jul 2012.

Submit your article to this journal $\pi$

Џ Article views: 50 


\section{TOWARDS THE INTEGRATION OF PROBABILISTIC RISK ANALYSIS WITH STRUCTURAL ANALYSIS}

\section{E. R. Vaidogas}

\section{Introduction}

In recent years an increased public and private interest in the safety of industrial facilities has led to an intensification of the research on the reliability of facilities and risk arising from their failures [1]. An analysis or, in other words, prediction of risk has gained considerable acceptance in some hazardous industries. The methodology of the probabilistic (quantitative) risk analysis (PRA) has been developed to cope with uncertainties related to the failures and their consequences.

PRA originated far from the traditional field of the civil and structural engineering, namely, in nuclear and chemical industries. Recently, an effort was made to apply PRA in a structural context, primarily to design and construction of the offshore installations in the petroleum industry [2-4].

A structural application of PRA is realised as an integration of PRA methods with the ones of the structural reliability analysis (SRA). Structural systems (buildings, engineering structures and services) are considered in PRA as parts of a higher-order system embodying natural or man-made hazards to which structures are exposed. A realisation of the hazards constitutes such structural phenomena as an imposition of abnormal loads and other extreme effects which may act on the structural system under analysis together with normal operating loads.

When severe accidents caused by human actions or natural phenomena are considered, the abnormal loads, i e loads imposed in the course of the accidents, are a natural interface between PRA and SRA, as also are other extreme effects which can be induced by the accidents. By the "interface" we mean the fact that the entire PRA problem of consideration of an adverse event sequence (accident scenario) including possible structural failures may be separated at least into two problems: (1) estimation of the characteristics of abnormal loads by PRA- specific methods and non-PRA methods of the theoretical (mathematical) and, what is also possible, physical simulation; and (2) estimation of the probabilities of structural failures and damages to non-structural components of the structural system under analysis which may be caused by abnormal loads. The latter problem is, of course, a structural one, whereas the first problem may lie far beyond the field of the structural engineering. The results obtained when solving the first problem are the initial data necessary to solve the second one.

An important problem related to a SRA, which takes into account abnormal loads, are uncertainties, first of all, aleatory (stochastic) and epistemic (state-of-knowledge) uncertainty concerning usually both properties of abnormal loads and structural response to them. The uncertainty of either type emerge eventually from the fact that severe accidents are generally rare and unexpected events; moreover, almost every severe accident as a whole is a complicated and difficult-to-repeat physical phenomenon.

In the present paper an integration of PRA with SRA is considered on the basis of the event tree analysis. The attention is focused on the event tree paths which comprise events of imposition of abnormal loads or other adverse effects on structural systems and their subsequent failures. The main finding consists in the fact that traditional quantitative event tree analysis even in combination with classical means of SRA may be insufficient for estimating frequencies of structural failures and thus risks arising from failures. The problem to be solved lies in the uncertainty of physical phenomena which precede structural events (failures, damages) and result in imposition of abnormal loads. A solution of the problem considered in this paper calls for a theoretical modelling of the just mentioned physical phenomena with the aim to establish a probabilistic model for the abnormal load in point. 


\section{Frequency and probability of structural failure}

The term "risk" is defined in PRA as a product of losses (consequences) and their frequency $[5,6]$. The risk is usually associated with an undesirable event which can initiate one of the $n$ foreseeable failures in the facility under consideration. The failures are modelled as exclusive random events imposing corresponding consequences $C_{i}(i=1,2, \ldots, n)$ which in turn are treated as random and measured usually in monetary units or number of deaths and injuries. The risk is commonly represented as a collection (spectrum) of $n$ pairs of failure frequencies $F_{i}$ and expected consequences $E\left[C_{i}\right]$ :

$$
\text { Risk } \equiv\left\{\left(F_{1}, E\left[C_{1}\right]\right),\left(F_{2}, E\left[C_{2}\right]\right), \ldots,\left(F_{m}, E\left[C_{n}\right]\right)\right\}
$$

The failure frequency or, in other words, the frequency of suffering of the $i$ th consequences $C_{i}$ is usually defined as

$$
F_{i}=F\left[A_{0}\right] P\left[C_{i} \mid A_{0}\right]=F\left[A_{0}\right] \prod_{j=1}^{m_{i}} P\left[A_{i j} \mid \bigcap_{k=0}^{j-1} A_{i k}\right],
$$

where $A_{i 0} \equiv A_{0}(i=1,2, \ldots, n) ; F\left[A_{0}\right]$ is the annual probability (frequency) of the initiating event $A_{0} ; P\left[C_{i} \mid A_{0}\right]$ is the probability of suffering of the consequences $C_{i}$ given $A_{0} ;\left(A_{i j}, j=0,1,2, \ldots, m_{i}\right)$ is the event sequence (path) leading to $C_{i} ; P[. \mid$.$] denotes the conditional probability.$ The probabilities $P\left[A_{i j} \mid.\right]$ are associated with corresponding branches of an event tree and are called the probabilities of branching points. Some of the events $A_{0}, A_{i 1}, \ldots, A_{i, m_{i}}$ may belong to another paths of the event tree under consideration, however, at least one event will be associated with the consequences $C_{i}$ only.

In the case when the consequences $C_{i}$ embrace losses due to structural failures the corresponding event sequence $\left(A_{i j}, j=0,1, \ldots, m_{i}\right)$ must include structural events. What follows it is assumed that there is only one possible structural event in the sequence $\left(A_{i j}, j=0,1,2, \ldots, m_{i}\right)$. This event is denoted by $A_{i . s}\left(0<s \leq m_{i}\right)$. The case when the adverse event sequence is initiated by structural failure under normal service conditions, i e $s=0$, is not considered.

A quantitation of the $i$ th risk $F_{i} \times E\left[C_{i}\right]$ is impossible without estimating the probability $P\left[A_{j, k} \mid \bigcap_{k=0}^{s-1} A_{i k}\right]$.
This probability is a conditional probability of the structural failure $A_{i s}$ given that the event sequence $\left(A_{i j}, j=0,1, \ldots, s-1\right)$ results in an imposition of a load causing the failure. The conditional probability of structural failure will be denoted by $P_{f}$ : Consequently, the frequency of the structural failure is expressed as

$$
F\left[A_{i s}\right]=F\left[A_{0}\right] \underbrace{\left(\prod_{j=1}^{k-1} P\left[A_{i,} \mid \bigcap_{k=0}^{j-1} A_{i k}\right]\right)}_{P_{I}} P_{f},
$$

where the term $P_{l}$ in the product on the right-hand side of $\mathrm{Eq}(1)$ is the probability of the event sequence which results in the imposition of a load on the structural system under consideration. Then the product $F\left[A_{0}\right] P_{l}$ is the frequency of the load imposition.

An estimation of the frequency $F_{k}$ related to an event tree path or generation of an uncertainty distribution describing the frequency is generally a relatively simple task if the event sequence in point, $\left(A_{k j}, j=0,1,2, \ldots, m_{k}\right)$, comprises readily identifiable events $A_{k j}$, such as "operator responds" or "operator does not respond" or else "power supply succeeds" or "power supply fails" (eg see $[3,5])$. An imposition of a load or other adverse effect on a structure in the course of an accident is not such event in most cases because intensity of the load, its distribution over a structure and other parameters are not known in advance. Consequently, a straightforward estimation of the conditional probabilities in $\mathrm{Eq}(1)$ and thus estimation of $F\left[A_{i s}\right]$ may be impossible because of uncertainties related to the accident course and thereby the process of load imposition.

Let a particular realisation of the accident course obtained by applying of a Monte Carlo simulation, ie a realisation of the event sequence $\left(A_{i j}, j=0,1, \ldots, s-1\right)$, be $\left(a_{i j}, j=0,1, \ldots, s-1\right)$ or, denoting more shortly, $a_{j}$. Then one can speak about the probability of structural failure conditioned on the realisation:

$$
P_{f}\left[A_{i, s} \mid a_{i}\right]=P_{f}\left[A_{i, s} \mid a_{i 1}, a_{i 2}, \ldots, a_{i, s-1}\right]
$$

If it is possible to simulate realisations like $a_{i}$ for all $n$ event tree paths, an estimation of the frequency of structural failure, $F\left[A_{i s}\right]$, can be performed by a simulation of $N$ outcomes $a_{0 r}(r=1,2, \ldots, N)$ of the initiating event $A_{0}$ and subsequent realisations of corresponding event sequences, $\boldsymbol{a}_{k \eta_{k}}\left(k=1,2, \ldots, n ; r_{k}=1,2, \ldots, N_{k} ; \sum_{k} N_{k}=\right.$ 
$N$ ). The set of realisations of the event sequence in question, $\boldsymbol{a}_{i r}\left(r=1,2, \ldots, N_{i}\right)$, will form a part of the realisations $a_{k n_{k}}$. Each $a_{i r}$ will comprise the lastly-simulated

component $a_{i, y-1, r}$ denoting an imposition of the load with parameters different for each $r$. For example, $a_{i, s-1, r}$ may be an effect of blast wave on a building with particular, that is, $r$ th initial peak overpressure and impulse.

Given the set $\boldsymbol{a}_{i r}\left(r=1,2, \ldots, N_{i}\right)$, one can choose a probabilistic model for parameters of the load under consideration, first of all, for its intensity or else estimate the frequency $F\left[A_{i s}\right]$ directly. In the latter case the most simple recipe is to use the averaging

$$
F_{e}\left[A_{i s}\right]=\frac{1}{N} \sum_{r=1}^{N_{i}} P_{j e}\left[A_{i s} \mid \boldsymbol{a}_{i r}\right]
$$

Here $F_{c}\left[A_{i s .}\right]$ and $P_{f_{i}}\left[A_{i, r} \mid a_{i r}\right]$ denote an estimate of $F\left[A_{i s}\right]$ and $P_{f}\left[A_{i, s} \mid a_{i r}\right]$, respectively.

In the case when an estimation of the probabilities $P_{f}\left[A_{i, s} \mid \boldsymbol{a}_{i r}\right]$ requires a considerable computational effort the simulation of accident courses may be applied to the choice of probabilistic models for the loads which impposition is modelled by the event $A_{\mathrm{i}, \mathrm{s}-\mathrm{l}}$. Such models may then be applied to the estimation of $F\left[A_{i s}\right]$.

The just mentioned probabilistic models express both aleatory and epistemic uncertainties inherent in the loads and are usually formulated as dependencies "intensity vs. probability" or "intensity vs. exceedance frequency". A choice of the models is well-established for the loads induced by hazardous natural phenomena, such as tornadoes or earthquakes (eg see [7 - 9]). The choice is accomplished on the basis of usually available meteorological, seismological, hydrological data. An imposition of the loads is usually considered as an initiating event $A_{0}$.

Contrary to the loads induced by hazardous natural phenomena the choice of a probabilistic model for a load which imposition $A_{i, s-1}$ is preceded by a sequence of adverse and usually non-structural events, $\left(A_{i j}, j=0,1\right.$, $2, \ldots, s-2)$, can hardly be based only or mainly on accident data, because such data are usually scarce and unreliable or even not available. A probabilistic model for a load in this case may be chosen via theoretical simulation of the physical processes preceding and including the load imposition, namely, using the set of realisations of event tree paths, $a_{k n_{k}}$.
If, for example, the initiating event $A_{0}$ represents a physical phenomenon having nearly-constant parameters for each outcome $a_{01}, a_{02}, \ldots$, the frequency of $A_{0}$ may be expressed by a single value $F\left[A_{0}\right]$ and estimated by a point estimate $F_{c}\left[A_{0}\right]$. Let us denote the intensity or other parameters of the load in question by $x$. A set of the predetermined intensity's values $x_{1}, x_{2}, \ldots$ will divide it into classes characterised by corresponding probabilities $P_{/ 1}, P_{l 2}, \ldots$, such that

$$
P_{l}=\sum_{\lambda} P_{l \lambda}
$$

The frequency of imposition of the load of any possible intensity was denoted earlier by the product $F\left[A_{0}\right] P_{l}$. Then the load with an intensity belonging to the $\lambda$ th class will be imposed with the frequency $F\left[A_{0}\right] P_{I \lambda}$. The probability $P_{l \lambda}$ may be estimated in the most simple way by the formula

$$
P_{l \lambda, e}=\frac{1}{N} \sum_{r=1}^{N_{i}} \mathbf{1}\left(a_{i, s-1, r}\right)
$$

where $P_{l \lambda, e}$ denotes an estimate of $P_{l \lambda}$ and $\mathbf{1}\left(a_{i, r-1, r}\right)$ is the zero-one variable equal to 1 if the simulated load intensity $a_{i, k-1, r}$ belongs to the $\lambda$ th class and equal to 0 otherwise. A probabilistic model for the load relating its intensity with exceedance frequency may be chosen by fitting a complementary distribution function $\mathcal{H}(x)$ to the cumulative frequencies $F_{c}\left[A_{0}\right] \times \sum_{t=\lambda}^{\Lambda} P_{l t, c} \quad(\lambda=1,2, \ldots, \Lambda)$, where $\Lambda$ is the number of intensity's classes.

An application of the probabilistic models like $\mathcal{H}(x)$ to the estimation of the frequency $F\left[A_{i s}\right]$ will be considered in $\operatorname{Sec} 4$ of the present paper.

\section{Example 1: problems of risk quantitation in the case of two types of accidental explosions}

Consider a liquefied petroleum gas (LPG) facility embodying several pressure vessels used for storage of LPG. A disturbance in the handling of LPG may lead to the release of the gas. This may be considered as an initiating event $A_{0}$. Given the initiating event, there may be several adverse event sequences that follow $A_{0}$ and result in the dangerous physical phenomena, such as major fire, UVCE, or BLEVE (see the event tree in Fig 1). Obviously, a realisation of such phenomena will impose ab- 


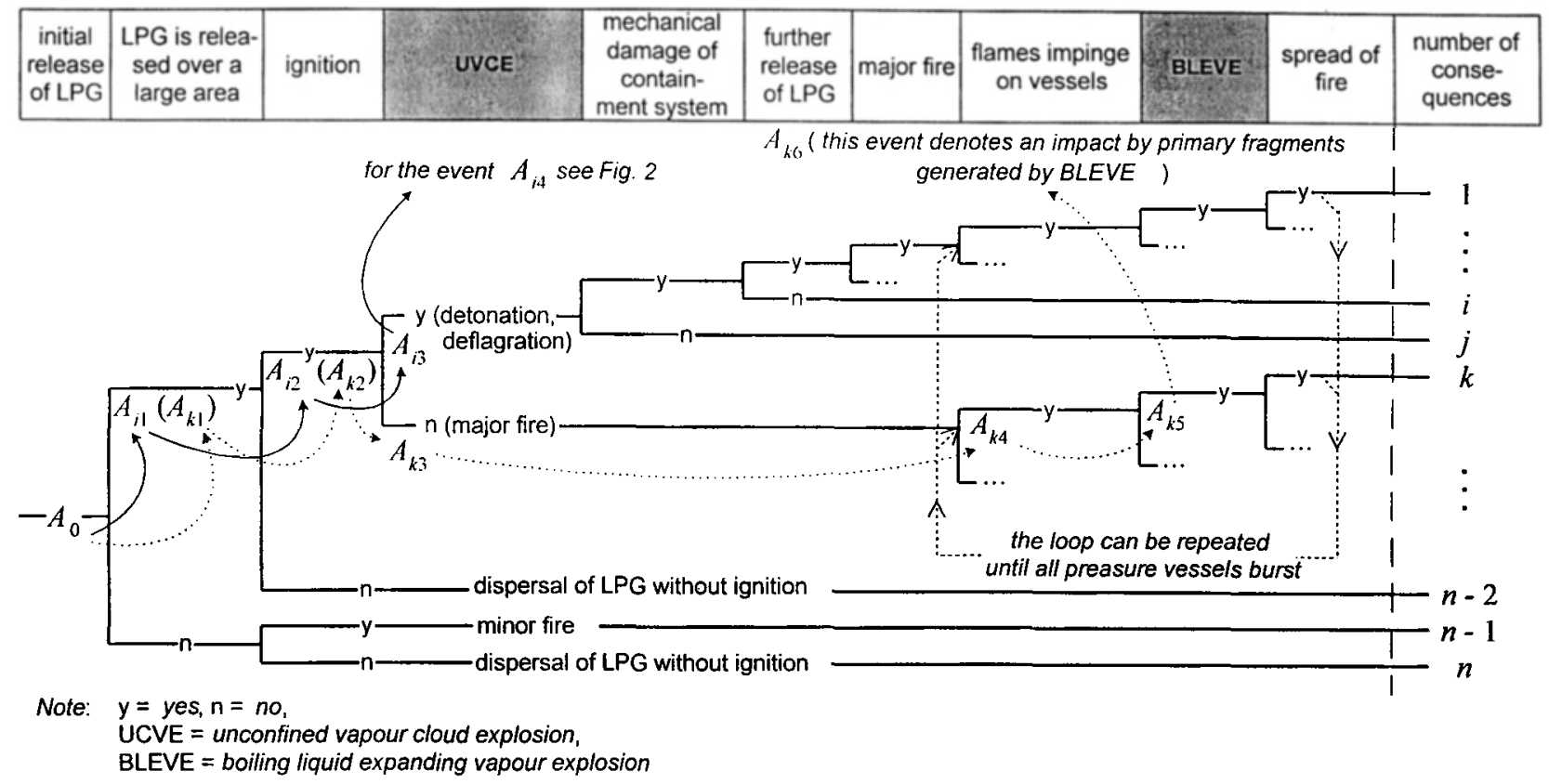

Fig 1. Event tree for the accident in the LPG facility initiated by a release of LPG (see the definition of the primary fragments in [10])

normal actions on structural systems located inside and outside the facility, namely extreme thermal effects, blast waves, impact of fragments.

Suppose that failures of the structural system under analysis will not have an influence of any significance on the course of the accident in the LPG facility. Thus, a separate event tree may be constructed in addition to the one shown in Fig 1 with the aim to discretise consequences of structural failures which may be caused, for example, by UVCE. This explosion should be taken as an initiating event of the separate event tree.

The degree of the discretisation of the consequences will depend upon the needs of the risk management which can be performed for the LPG facility or the structural system in point or for both. One such discretisation is shown in Fig 2. The identified consequences should be taken as a part of the overall consequences associated with the relevant paths of the event tree from Fig 1, primarily with the $i$ th and $j$ th paths.

Turning back to the above-introduced notation, consider the event sequence $\left(A_{i l}, l=0,1,2,3,4\right)$. It is associated with the $i$ th path of the event tree plotted in Fig 1. The event $A_{i 1}$ means the release of an amount of LPG which is large enough to create in the case of ignition

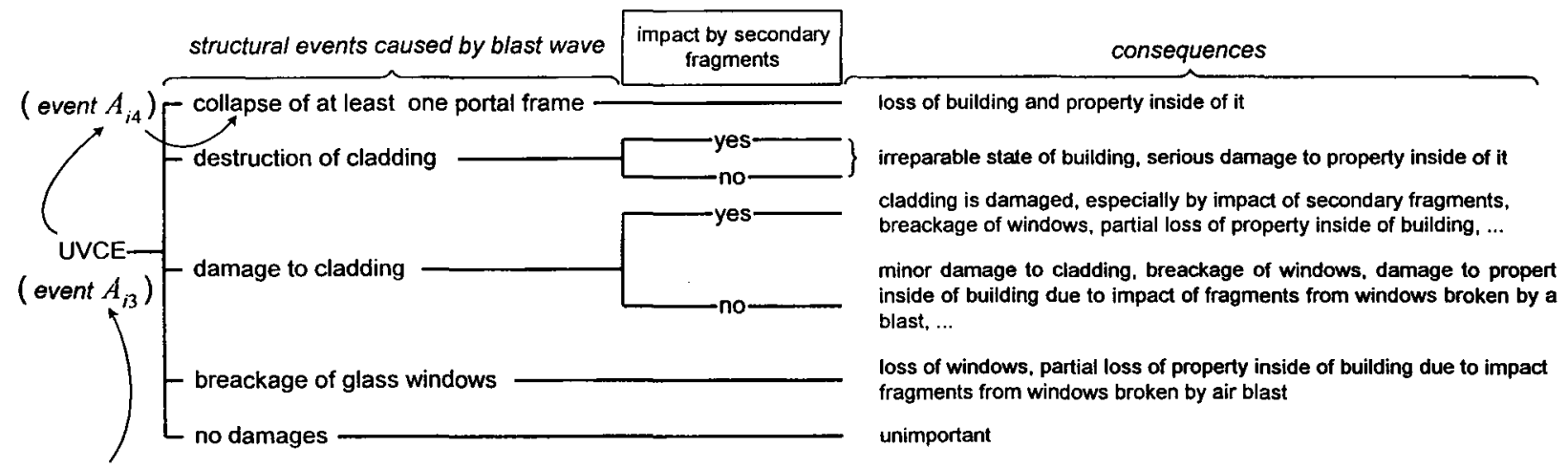

for the events $A_{0}, A_{i 1}$ and $A_{i 2}$ see Fig.1

Fig 2. Discretisation of consequences imposed by UVCE in vicinity of a portal framed reinforced concrete building under the assumption that the building is not captured by the vapour cloud before UVCE (see the definition of the secondary fragments in [10]) 
blast waves having destructive mechanical effects (see [10] for specific values). The last event of the sequence, $A_{i 4}$, means "collapse of at least one portal frame" due to the blast wave induced by UVCE (see Fig 2). The event $A_{i 4}$ may be considered as independent of the events $A_{i 0}$ to $A_{i 2}$. Consequently, one can write that

$$
P_{f}=P\left[A_{i 4} \mid \bigcap_{i=0}^{3} A_{i l}\right]=P\left[A_{i 4} \mid A_{i 3}\right]
$$

and

$$
F\left[A_{i 4}\right]=F\left[A_{0}\right] \prod_{l=1}^{3} P\left[A_{i l} \mid \bigcap_{k=0}^{l-1} A_{i k}\right] P_{f}
$$

where $P_{f}$ is the probability of the collapse of at least one portal frame given the event of an imposition of the blast load, $A_{i 3} ; F\left[A_{i 4}\right]$ is the frequency of suffering the consequences due to the occurrence of the event $A_{i 4}$.

Consider further the $k$ th path of the event tree plotted in Fig 1 . The event sequence $\left(A_{k l}, l=0,1, \ldots, 6\right)$ comprising this path includes the event $A_{k 5}$ which denotes an occurrence of an explosion called BLEVE. The physical phenomenon of BLEVE is characterised by an extreme heat radiation and generation of small number of large primary fragments [10]. The event of structural nature, $A_{k 6}$, denotes the "impact by primary fragments" generated by BLEVE and thereby incurring losses due to local damages to building hit by the fragments. The frequency of BLEVE is expressed as follows:

$$
F\left[A_{k 5}\right]=F\left[A_{0}\right] \prod_{l=0}^{5} P\left[A_{k l} \mid \bigcap_{t=1}^{l-1} A_{k t}\right]
$$

The event $A_{k 6}$ may be considered as independent of all prior events except $A_{k 5}$ because probability of $A_{k 6}$ is not changed by an occurrence of any of $A_{k i 1}, \ldots, A_{k 4}$. Consequently, the frequency of the load imposition (hitting the building under consideration by primary fragments) is given by the product $F\left[A_{k 5}\right] \times P\left[A_{k 6} \mid A_{k 5}\right]$. The probability $P\left[A_{k 6} \mid A_{k 5}\right]$ expresses the likelihood of any hitting of the building by any number of fragments which can be generated by the explosion.

A quantitative analysis of the event tree shown in Fig 1 can allow to estimate frequencies of such events as UVCE or BLEVEs. However, an additional theoretical simulation is necessary to estimate probabilities of structural failures (damages to structures), $P_{f}$, which are equal in the case of UVCE and BLEVE to $P\left[A_{i 4} \mid A_{i 3}\right]$ and $P\left[A_{k 6} \mid A_{k 5}\right]$, respectively. The concrete values of probabilities $P\left[A_{i 4} \mid A_{i 3}\right]$ and $P\left[A_{k 6} \mid A_{k 5}\right]$ will depend upon how the respective event sequences $\left(A_{i j}, j=0,1,2,3\right)$ and $\left(A_{k l}, l=0,1, \ldots, 5\right)$ will realise in a particular accident. With this fact in mind, the frequencies of the structural events, $F\left[A_{i 4}\right]$ and $F\left[A_{k 6}\right]$, should be estimated taking into account all possible realisations of corresponding event sequences.

\section{Normal and abnormal loads}

The load, the imposition of which is denoted in the foregoing by the event $A_{i, s-1}$ occurring in the course of an accident, will act on structural system under consideration together with the loads applied to it at the moment of occurrence of $A_{i_{1}-1}$. It has been suggested in PRA to categorise all foreseeable loads which may be applied to a structural system during its lifetime into normal and abnormal ones $[4,11]$.

Let $\mathcal{S}$ be an event consisting in an imposition of a normal load (combination of loads) or being an intersection of the events that lead to such imposition. Then the intersection $\bigcap_{k=0}^{s-1} A_{i k}$ denoted below by $\mathscr{A}$ will be a history of imposition of an abnormal load (combination of loads) if relatively to the lifetime of the structural system in point the probability $P[\mathscr{A} \cap \mathscr{V}]$ will be considerably lesser than $P[\mathcal{X}]$ as well as the probability $P\left[A_{i s} \mid \mathscr{A} \cap \mathcal{X}\right]$ will be considerably larger than $P\left[A_{s} \mid \mathcal{Y}\right]$, where $A_{s}$ denotes the occurrence of the same structural failure as does $A_{\text {is: }}$

In all likelihood, the categorisation of the foreseeable loads into normal and abnormal ones arises from the classification of risks related to two opposite types of adverse events, namely, low-frequency/high-probability events and high-frequency/low-probability ones. However, it would be appropriate to supplement the categorisation of loads according the frequency/consequence ratio by another two attributes, namely, quality and amount of statistical data (observations of loading histories) as well as treatment of the load in the structural design.

Normal operating loads may be simply defined as those which will be imposed on a structure with a high probability during the period of interest and which, of course, are taken into account in the design of the structure. Further attribute of the "normality" is that there is a 
relative low degree of uncertainty in respect of intensities and sometimes frequencies of applying the loads due to available and proper statistical data.

Properly designed and built structures exposed to normal operating loads can hardly be of interest to the risk management for as long as it is possible to assure explicitly (by applying SRA) or implicitly (with usual semiprobabilistic methods of structural design) such level of reliability that structural components of a facility could be seen as failproof as compared to nonstructural ones (mechanical, electrical, electronic). The only point that should be mentioned here is that structures exposed to normal loading conditions can fail due to human errors committed in their design and construction. Such failures should be treated in the risk management as lowprobability initiating events. For example, failures of such hazardous structures as dams may at least in $82 \%$ of cases be considered as caused by human errors in their design (see Sec 2.2 in [12]). Moreover, it is stated that about $50 \%$ of dam failures occurred without extreme flood or earthquake loading, thus under normal loading conditions [13].

An abnormal load may be defined as one lacking at least one of the two attributes of normal operating loads. The loads which are in principle possible but unlikely to be imposed may be simply neglected in the design of facility usually due to a limited construction budget, or, alternatively, structures inside of the facility may be designed to withstand only rather limited intensities of such loads. The latter situation arises also in the case when an insufficient amount of observations is available and it is impossible to predict with a fair degree of confidence maximal intensities of the loads during the period of interest.

Abnormal loads of short duration are usually imposed by natural or man-made hazardous phenomena which are generally rare in occurrence. As defined above, loads of a relatively long duration may also be treated as abnormal ones if their intensities may significantly exceed design values in very few cases or even once during the design life of facility (structural system).

\section{Example 2: two types of abnormal loads}

Two examples of abnormal loads are loads imposed by accidental explosions of pressure vessels inside (out- side) of buildings and hydrostatic inflow forces acting on dams during extreme floods.

The explosions of pressure vessels are rare instantaneous events. For instance, the rate of explosive failures for steam boilers is $5.8 \times 10^{-4}$ per vessel year and $1.8 \times 10^{-5}$ per vessel year for other vessels (German data collected in 1959-76 and cited in [14]). Mechanical characteristics of blast wave and impact by fragments generated by an explosion have a sufficient degree of uncertainty and usually can be statistically described only by results of back-analyses (post-mortem investigations) of a small number of accidents with similar equipment and in similar facilities. An example of one of the back-analyses can be found in [15].

The abnormal loads mentioned here as a second example, namely, hydrostatic inflow forces imposed on dams during extreme floods are loads of long duration as compared with the ones generated by accidental explosions. The possibility of extreme floods is naturally taken into consideration in the design of every dam. Despite of this fact, the hydrostatic loads should be treated as abnormal ones due to scarcity and uncertainty of data about extreme floods. Short duration of available historical flood records and extreme variability of streamflows above dams caused that to date there is no methodology to assign reliably probabilities of extreme flood events [13].

\section{Integration of SRA with PRA}

In the case when a problem of SRA is considered in the framework of PRA, at least one basic variable relevant to the problem and modelling an intensity of abnormal load or other adverse physical phenomenon, $x$, may be represented by a family of hazard functions (curves) $\mathcal{H}_{k}(x)(k=1,2, \ldots)$, each relating values of the basic variable with the annual probability that the values will be exceeded and reflecting different subjective degree of believe in the relationship (see Fig 3 (a)). As an example one can refer to the family of the 10 hazard functions used in the seismic risk assessment and characterising the peak ground acceleration [7].

Each family of hazard functions is in essence established to express the epistemic uncertainty relative to the relation between physical phenomenon in point and annual exceedance probabilities. If abnormal loads are con- 


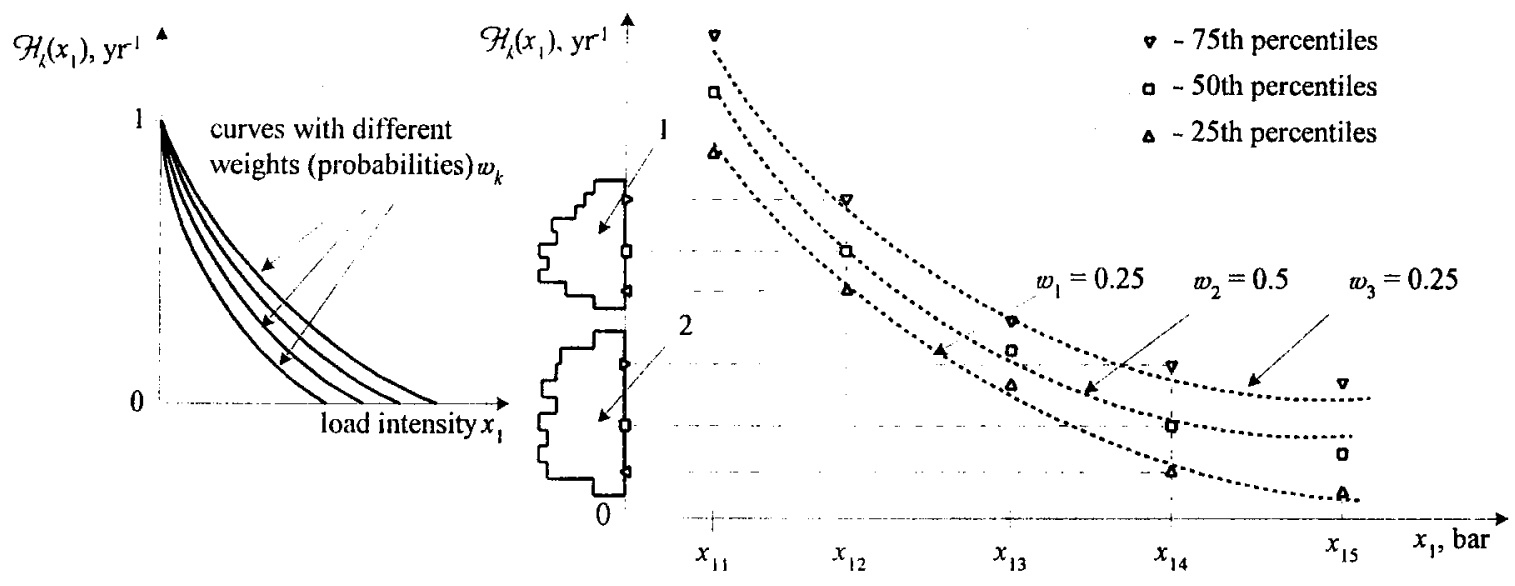

(a)

(b)

Fig 3. Hazard curves "peak overpressure $x_{1}$ vs. annual probability of exceedance $\mathcal{H}\left(x_{1}\right)$ ": (a) general representation, (b) as a result of an uncertainty modelling (values $x_{11}, x_{12}, \ldots, x_{15}$ are predetermined intensities); $1=$ distribution of uncertainty in frequency of exceedance of the value $x_{12}, 2$ the same for the value $x_{14}$

sidered, one can expect that in most practical cases we will have to deal with a considerable degree of the epistemic uncertainty. A usual way to quantify the uncertainty is an assignment of weights (probabilities) $w_{k}$ to corresponding hazard functions $\mathcal{H}_{k}\left(x_{1}\right) \quad\left(\Sigma_{k} w_{k}=1\right.$ ) (eg see [8]).

Let the basic variable representing an abnormal load be $X_{1}$ and the corresponding hazard functions be $\mathscr{H}_{k}\left(x_{1}\right)$. If there is no uncertainty in the remaining basic variables making up the vector $\left(X_{2}, X_{3}, \ldots\right)^{T}$ denoted in following by $X^{\prime}$ as well as in the limit state functions (LSFs) $g_{j}\left(x_{1}, x\right)$, the $k$ th annual probability of structural failure, $F_{k}\left[A_{i s}\right]$, is estimated from the formula which is wellknown in PRA as the convolution of the kth hazard function and fragility function, namely,

$$
F_{k}\left[A_{N}\right]=\int_{0}^{\infty}\left|d \mathcal{H}_{k}(z) / d z\right| z=x_{1} \mid P_{f}\left(x_{1}\right) d x_{1},
$$

where $P_{f}\left(x_{1}\right)$ is the conditional probability of structural failure given the intensity of abnormal load $x_{1}$. This probability is called in PRA the fragility function and expressed by

$$
P_{f}\left(x_{1}\right)=\int_{\left\{x^{\prime}: \vee_{j}\left(g_{j}\left(x_{j}, x^{\prime}\right) \leq 0\right)\right\}} d H_{X^{\prime}}\left(x^{\prime}\right),
$$

where $H_{X^{\prime}}($.$) is the cumulative distribution function$ (CDF) of $X^{\prime} ; x^{\prime}$ denotes a value of $X^{\prime}$; and the symbol $v_{j}$ denotes "for at least one $j$ ".

With the frequencies $F_{k}\left[A_{i s}\right]$ one can establish a distribution of uncertainty relative to the frequency of structural failure

$$
H_{F\left[A_{i .,}\right]}(f)=P\left[F\left[A_{i, s}\right] \leq f\right]=\sum_{F_{(k)}\left[A_{i s}\right] \leq f} w_{(k)} .
$$

Here the frequencies $F_{(k)}\left[A_{i s}\right]$ are obtained by arrangement in ascending order the frequencies $F_{k}\left[A_{i s}\right] ; w_{(k)}$ are correspondingly rearranged weights. For example, if $F_{(1)}\left[A_{i s}\right]$ equals to $\min _{k}\left\{F_{k}\left[A_{i s}\right]\right\}$, and if the number $k$ of the smallest $F_{k}\left[A_{i s}\right]$ equals to, say, 3 , then $w_{(1)}=w_{3}$.

An establishing of a family of hazard functions for an abnormal load in question is generally a problem lying outside of SRA, although this task may be an indispensable part of a PRA. Even if such family is already available for the analyst participating in the PRA, he (she) may be confronted with the need to cope with other kinds of epistemic and/or aleatory uncertainty regarding primarily structural aspects, as for instance, process of load imposition, distribution of load over a building, structural response to the load, or sequence of structural failures caused by it. As an example one can mention the problem of modelling by probabilistic means of effects of a blast wave generated by an accidental explosion near the building of interest and response of the building to the wave. In spite of several deterministic models suggested 
to date, a well-established and verified probabilistic models seem not to be available (eg see $[15,16]$ ). The analyst seeking to quantify risks related to the explosion will in all likelihood have to combine the deterministic models with modelling uncertainties inherent in both LSFs $g_{j}\left(x_{1}, x\right)$ and CDFs of basic variables used in corresponding SRA.

The epistemic uncertainties related to the parameters of $g_{j}($.$) or H_{X^{\prime}}($.$) or else to "competitive" g_{j k}($.$) or H_{X k}($. may be regarded by expressing the fragility function $P_{f}\left(x_{1}\right)$, which was previously defined by $\mathrm{Eq}(3)$, as a weighted mean. For example, if there is an uncertainty in some parameters $\pi$ of $H_{X^{\prime}}($.$) , the fragility function may be$ expressed as

$$
P_{f}\left(x_{1}\right)=\int_{111 \pi} P_{f}\left(x_{1} \mid \pi\right) d H_{\pi}(\pi)
$$

where $P_{f}\left(x_{1} \mid \pi\right)$ is the conditional failure probability given the vector of parameters of basic variables, $\pi ; H_{\nearrow}($.) is the CDF reflecting the uncertainty related to the parameters of $H_{X}$ (.) which are modelled by the random vector $\Pi$ (epistemic uncertainty). The probability $P_{f}\left(x_{1} \mid \pi\right)$ is given by

$$
P_{f}\left(x_{1} \mid \pi\right)=\int_{\left\{x^{\prime}: \vee_{j}\left(g_{j}\left(x_{1}, x^{\prime}\right) \leq 0\right)\right\}} d H_{\lambda^{\prime \prime}}\left(x^{\prime} \mid \pi\right) .
$$

In the case at hand an estimation of the uncertainty distribution of annual structural failure probability, $H_{F\left[A_{i s}\right]}(f)$, will require a considerable computational effort because of the need of a repeated estimation of the probabilities $P_{f}\left(x_{1}\right)$ and $P_{f}\left(x_{1} \mid \pi\right)$ given by Eqs (3) and (4), respectively.

The amount of computations with the aim to estimate $H_{F\left[A_{i,}\right]}(f)$ may also be large in the case when several fragility functions $p_{f k}\left(x_{1}\right)$ with subjectively assigned weights $w_{k}$ are used in a SRA problem. In this case values of $P_{f}\left(x_{1}\right)$ used for an evaluation of the integral in Eq(2) should be computed by the formula

$$
P_{f}\left(x_{1}\right)=\sum_{k} P_{f k}\left(x_{1}\right) w_{k}
$$

The computations according to the formulas (2) and (3) as well as (4) - (6) may be costly in a computational sense, however, they are inescapable if we want to take proper account of uncertainties to be reckoned with in almost all PRAs embracing risks which arise from failures of structural systems.

Subjective schemes for the choice of a family of hazard functions, $\mathcal{H}_{k}\left(x_{1}\right)$, seems to be poorly investigated at least in the sense regarding a creation of generally recognised schemes which could be used for such choice [17]. In the following example it is attempted to show how such family may be chosen for the load imposed by an explosion which can endanger structural systems.

\section{Example 3: problems related to establishing hazard functions for UVCE}

Consider again the adverse event sequence $\left(A_{i l}, l=0,1,2,3,4\right)$ from the Example 1 . The event $A_{i 3}$ represents the phenomenon of UVCE, that is a combustion of an unconfined vapour cloud in the mode of detonation (see definition of UVCE, for instance, in [10]). The opposite combustion mode is a deflagration. The detonation is characterised by a high biast wave velocity and pressure at the wave front, whereas the deflagration can generate a blast wave of moderate or low velocity and pressure at its front or else can proceed creating a negligible blast wave $[10,16]$.

Although the detonation and deflagration are different by their physical nature, a probabilistic modelling of mechanical effects of either combustion mode should be made by a common family of hazard functions which will cover the entire range of possible intensities of the effects. For example, the initial peak overpressure falls within the range 1 to $1400 \mathrm{kPa}$ for both modes of combustion of many types of gases, whereas the range of the overpressure induced by deflagration of heavy hydrocarbon vapours (propane, butane, pentane) is from 20 to $70 \mathrm{kPa}$ $[18,19]$. From the considerations just mentioned, the random event $A_{i 3}$ given in the tree shown in Fig 1 denotes both detonation and deflagration of a vapour cloud. The opposite event $A_{k 3}$ denotes a deflagration with a blast wave negligible from the structural point of view, say, a blast wave which cannot break windows in the building(s) placed in the area of potential spreading of the vapour cloud.

The probabilities how a combustion will occur, $P\left[A_{i 3} \mid A_{0} \cap A_{i 1} \cap A_{i 2}\right]$ and $P\left[A_{k 3} \mid A_{0} \cap A_{k 1} \cap A_{k 2}\right]$, can be estimated by repeated simulation of the process "release 
of LPG - formation of vapour cloud - ignition of vapour cloud". Of course, such simulation will require to utilise the empirical deterministic models relating to the socalled non-dimensional pressure and reduced (scaled) impulse with reduced (scaled) distance of the building under analysis to the centre of the flammable vapour cloud (eg see [10, 19]).

In [18], a probabilistic model has been proposed for an estimation of the conditional probability of an asymmetric ignition of a vapour cloud, $P\left[A_{i 2} \mid A_{0} \cap A_{i 1}\right]$, and thus of the ignition frequency $F\left[A_{i 2}\right]$ equal to the product $F\left[A_{0}\right] \times P\left[A_{i 1} \mid A_{0}\right] \times P\left[A_{i 2} \mid A_{0} \cap A_{i 1}\right]$. With the probabilistic model allowing to estimate the frequency $F\left[A_{i 2}\right]$ one can assess, at least in principle, frequencies of exceeding of predetermined intensities of such explosion effects as initial peak overpressure or impulse. To do this, the aforementioned deterministic models "non-dimensional pressure vs. reduced distance" or "reduced impulse vs. reduced distance" will be indispensable. However, such models are uncertain per se and do not take proper account of several important factors, such as exact form of an usually disk-shaped vapour cloud, various characteristics of potential ignition sources, or largely random distribution of vapour concentration inside the cloud. This in turn will require to give proper weight for modelling epistemic uncertainties stemming from the deterministic models.

A family of hazard functions, $\mathcal{H}_{k}\left(x_{1}\right)$, for the intensity of a mechanical explosion's effect, say, the initial peak overpressure $x_{1}$, should be established by a propagation of the epistemic uncertainties on the level of probabilistic and deterministic models of vapour cloud formation, spreading and ignition to the level of frequencies with which certain predetermined intensity's values are exceeded. In PRA, such propagation is usually done by applying the Monte Carlo simulation (see $[3,5]$ for examples). A result of such simulation will be samples of exceeding frequencies related to the predetermined overpressure values, say, $x_{11}, x_{12}, \ldots, x_{15}$ (see Fig $3(\mathrm{~b})$ ). The family of hazard functions may then be chosen by a fitting of probabilistic models in the manner shown in Fig 3 (b).

\section{Concluding remarks}

Using the event tree approach as the base for the adverse event sequences (event tree paths) comprising im- position of abnormal loads on structural systems and their subsequent failure (damage) were analysed. The attention was centred on the fact that such adverse event sequences possess a high degree of uncertainty related to realisations in a particular accident of the physical phenomena from initiating event to imposition of abnormal load(s) on structural system in point. An estimation of frequencies of structural failure in this situation should be preceded by a choice of a probabilistic model, usually a family of hazard functions, which will express the aleatory and epistemic uncertainties related to the abnormal load(s) being considered. To do this the traditional event tree analysis should be supplemented by a theoretical simulation of accident scenarios, i e sequences of the physical phenomena leading to and including an imposition of the abnormal load(s). Given a family of hazard functions chosen for an abnormal load, the frequencies of structural failures may be estimated in the way common in PRA, namely, by a numerical evaluation of the integral called in PRA the convolution of a hazard function and structural fragility function.

\section{References}

1. O. J. Tveit. Risk analysis in risk management: Have we seen the benefits in practical industrial applications? // Proc. of European conf. on safety and reliability ESREL'98. Ed. by S. Lydersen et al. Vol. 1. Rotterdam: Balkema, 1998, p. 3-7.

2. T. Aven, W. Rettendal. Bayesian Frameworks for Integrationg PRA and SRA methods // Structural Safety, Vol. 20, 1998, p. 155-165.

3. W. K. Rettedal. Quantitative risk and reliability analysis in construction and marine operations of offshore structures. $\mathrm{Ph}$. D. thesis, Stavanger Univ. College and Aalborg Univ., 1997. $124 \mathrm{p}$

4. T. Moan. Reliability and risk analysis for design and operations planning of offshore structures // Proc. of 6th int. conf. on structural safety and reliability ICOSSAR'93. Ed. by G. I. Shueller et al. Vol. 1, Rotterdam: Baikema, 1994, p. $21-43$.

5. H. Kumamoto, E. I. Henley, Probabilistic risk assessment for engineers and scientists, 2nd ed. New York: IEEE Press, 1996. $597 \mathrm{p}$.

6. T. Aven. Peliability and risk analysis. London etc.: Elsevier, 1992. $346 \mathrm{p}$.

7. M. K. Ravindra. Seismic risk assessment // Probabilistic structural mechanics handbook. Ed. by C. Sundararajan, New York: Van Nostrand, Reinhold, 1993, p. 429-464.

8. A. Yamaguchi. Partial correlation consideration in quantitation of seismic failure sequences of a fast breadr reactor // Proc. of 6th int. conf. on structural safety and reliability ICOSSAR' 93 . Ed. by G. I. Shueller et al. Vol. 3, Rotterdam: Balkema, 1994, p. 2255-2270. 
9. R. H. Sues at al. Integrating internal events in an external event probabilistic risk assessment: tornado PRA case study // Reliability enginering and system safety, Vol. 40, No 1, 1993, p. 173-186.

10. W. E. Baker et al. Explosion hazards and evaluation. Amsterdam: Elsevier, 1983. $807 \mathrm{p}$.

11. C. Sundararajan(Raj), V. VoTroung. Probabilistic Structural Mechanics in System and Plant Risk Assessment // Probabilistic Structural Mechanics Handbook. Ed. by C. Sundararajan, New York: Van Nostrand, Reinhold, 1993, p. $188-210$.

12. E. S. Kalustian. Destruction and Damage of Concrete Dams on Rock Foundations. Moscow etc.: AO VNIIG Publ., 1997. $188 \mathrm{p}$.

13. P. Henrichs and R. Fell (eds.). Acceptable risks for major infrastructure. Rotterdam: Balkema, 1995. 203 p.

14. L. P. Harrop. The Integrity od Pressure Vessels // Science Progress, Vol. 68, 1983, p.423-457.

15. A. V. Watson. The response of civil engineering structures to impulsive loads // Proc. of 3rd int. conf." "Structures under shock and impact". Ed. by P. S. Bulson, Southampton, Boston: Computational Mechanic Publications, 1994, p. $3-10$

16. P. Bailly et al. Accidental explosions near buildings, methodology of the valuation of the effects // Proc. of 6th int. conf. on structural safety and reliability ICOSSAR'93. Ed by G. 1. Shueller et al. Vol. 3, Rotterdam: Balkema, 1994 , p. 1929-1932.

17. F. Casciati, L. Faravelli. Fragility analysis of complex structural systems. New York etc.: Willey, 1991. 413 p.

18. G. Odisharia et al. Risk analysis of sour gas processing complex in Russia // Proc. of european conf, on safety and reliability ESREL'98. Ed. by S. Lydersen et al. Vol. 2. Rotterdam: Balkema, 1998, p. 865-872.

19. A. A. Borisov et al. On modelling of pressure waves forming by detonation and combustion of gas mixtures // The physics of combustion and explosion. Vol. 21. No 2 , 1985, p. 90-97.

Iteikta 19990408

\section{TIKIMYBINÉS RIZIKOS ANALIZĖS IR KONSTRUKCI- JU ANALIZĖS INTEGRAVIMO KLAUSIMU}

\section{E. R. Vaidogas}

S a n t r a u k a

Nagrinejjamas tikimybinès rizikos analizès (TRA) ir tikimybinès konstruciju analizès (TKA) integravimas. Logine grandimi, susiejancia TRA su TKA, laikomos apkrovos, kurios veikia konstrukcines sistemas avariju, galinciu ịykti pramoniniuose objektuose, metu. Siūloma bendrają TRA problemą dalyti i dvi: (1) tikimybinio avariniu apkrovų modelio parinkima derinant TRA metodus su teoriniu avarinių procesų modeliavimu bei (2) konstruciju avariju tikimybiu vertinimą TKA metodais, kartu naudojant anksciau parinktus avarinių apkrovų modelius.

Tikimybinis rizikos vertinimas straipsnyje aptariamas remiantis ivykiu medžio analize. Nagrinejjamos ivykiụ medžio šakos, kurios apima avariniu apkrovų pridejimą ir jų nulemta konstrucijy suirimą ar pažeidima. Nustatyta, kad tradicinès kiekybinès ivykiu medžio analizès priemonès gali būti nepakankamos, vertinant konstrukciju avariju dažnius net ir tada, kai šios priemones yra derinamos su klasikiniais TKA metodais. Tai lemia didelis fiziniu procesu, modeliuojamy ivykiu medžio šaka, neapibrèžtumas. TRA ir TKA derinimo problema yra ta, kad iš anksto nežinoma, kokio intensyvumo avarines apkrovos pasireik $̌$ konkretaus scenarijaus avarijos eigoje.

Kaip tikimybiniai apkrovų modeliai TRA uždaviniuose paprastai yra naudojamos rizikos funkcijos (angl. hazard functions). Pasiūlyta, kaip parinkti rizikos funkciju šeimą apkrovai, kurios pridejimą lemia keletas fiziniu procesu (ivykiu), sukeliančiu šią apkrovą. Ši rizikos funkcijų Šeima išreiškia stochastini ir pažintini (angl. state-of-knowledge) neapibrèžtuma avarinés apkrovos intensyvumo atžvilgiu. Parodyta, kaip panaudoti pasirinktają rizikos funkciju šeimą vertinant konstrukcijų avarijos dažni ir kaip pateikti tokio vertinimo rezultatus.

Išnagrinèti trys pavyzdžiai apie avarijas pramoniniuose objektuose ir su jomis susijusias apkrovas. Daugiausia demesio skirta apkrovoms, kylančioms avarinių sprogimų metı.

Egidijus Rytas VAIDOGAS. Senior Assistant, Doctor. Dept of Reinforced Concrete Structures. Vilnius Gediminas Technical University, Saulètekio al. 11, 2040 Vilnius, Lithuania; e-mail: erv@st.vtu.It

PhD (building structures, 1994). Since 1995 senior assistant at the Dept of Reinforced Concrete Structures. In 1993, 1996-97 research visits to Bauhaus University Weimar (Germany). Research interests: reliability-based structural analysis and design. 